\title{
Thoracoplasty-Current View on Indication and Technique
}

\author{
Oleg Kuhtin ${ }^{1}$ Marina Veith ${ }^{1}$ Mohammed Alghanem ${ }^{1}$ Ivan Martel ${ }^{2}$ Dmitrii Giller $^{2}$ Viktor Haas ${ }^{3}$ \\ Ludwig Lampl ${ }^{4}$
}

${ }^{1}$ Clinic for General, Visceral and Vascular Surgery,

Caritas-Krankenhaus Bad Mergentheim, Bad Mergentheim,

Germany

${ }^{2}$ Clinic for Thoracic Surgery and Tuberculosis, I.M. Sechenov Moscow

Medical Academy, Moscow, Russian Federation

${ }^{3}$ Clinic for Thoracic Surgery, Klinikum Ansbach, Ansbach, Germany

${ }^{4}$ Clinic for Cardio- and Thoracic Surgery, Klinikum Augsburg,

Augsburg, Germany

Thorac Cardiovasc Surg 2020;68:331-340.

\begin{abstract}
Address for correspondence Oleg Kuhtin, Clinic for General, Visceral and Vascular Surgery, Caritas-Krankenhaus Bad Mergentheim, GmbH, Uhlandstr. 7, Bad Mergentheim 97980, Germany

(e-mail: olegkuhtin@yahoo.de).
\end{abstract}

\begin{abstract}
Keywords

- thoracoplasty

- pleural empyema

- pneumonectomy

- tuberculosis

- aspergilloma

Thoracoplasty was invented for removing cavities between thoracic wall and remnant lung or mediastinum. It was initially used in cases of tuberculosis or unspecific infections, while currently it is used mainly for space problems after lobectomy/ pneumonectomy.

This article presents an overview of the historical and current techniques of this surgical procedure.

Nowadays, thoracoplasty is rarely performed due to the low incidence of diseases for which this method is necessary. Therefore, this method has even been discredited. Furthermore, certain technical aspects of the thoracoplasty are not very well known because of the infrequent application of this procedure.

Unfortunately, a look into the literature of thoracoplasty is not always usefull due to the biased views of advocates of different techniques such as Schede's thoracoplasty, Heller's Jalousie-Plastik, Alexander's extramusculoperiosteal thoracoplasty, Bjork's osteoplastic thoracoplasty, etc.

Not to forget, there has always been a lack of research on the relevance and on the several techniques of thoracoplasty.

The point is precise indication and correct execution of thoracoplasty as a final therapeutic option, which allows a safe and definitive solution of the space problem even in complex cases, without creating serious functional and cosmetic impairment for the patient.

The main types of thoracoplasty are described in this article. Although the core principle of this operation remains unchanged, modern techniques are often cosmetically more considerable and less destructive, compared with techniques that were used in the past.
\end{abstract}

received

December 16, 2017

accepted after revision

March 12, 2018

published online

May 17, 2018
(C) 2020 Georg Thieme Verlag KG

Stuttgart · New York
DOI https://doi.org/

10.1055/s-0038-1642633.

ISSN 0171-6425. 


\section{Introduction}

Thoracoplasty means resection of bony parts of the chest wall, usually more or less extended parts of the ribs. The aim of the procedure is to reduce the size of the chest wall to eliminate a hollow space, or to compress a pathologically altered lung. ${ }^{1-4}$

This surgical method (also called collapse therapy of chest wall) historically applied to treat cavernous forms of lung tuberculosis and to eliminate empyematous cavities. ${ }^{3,5}$ Gradually, the technique of thoracoplasty has been significantly modified $^{6}$ and currently it is complemented frequently by a myoplasty such as thoracomyoplasty. ${ }^{7}$

Thoracoplasty was initiated in the late 19th century to treat destructive lung tuberculosis and was also a "last chance" treatment for chronic pleural empyema (in various intra/extrapleural modifications with different degrees of mutilation). ${ }^{1,4,6,8}$ The need for surgical intervention was considerably reduced as a result of the introduction of effective drug therapy of tuberculosis (starting with Streptomycin in 1944, then PAS, INH, and most recently Rifampicin, in 1966) as well as the development of multimodal and targeted treatment of pleural empyema.

The precise technique and indication of thoracic modelling has largely fallen into oblivion. In consequence, during the past 30 years, thoracoplasty is rarely performed and when performed, it is often done incorrectly.

Although surgery in the treatment of the pulmonary tuberculosis is currently of no great relevance, the importance of thoracoplasty has not decreased, especially in cases of infected intrathoracic cavities, which cannot be liquidated otherwise (e.g., after pulmonary resection). Thoracoplasties in particular represent a safe and life-saving treatment option in cases of permanent space infections after pneumonectomy (up to $10 \%)^{9,10}$

It should be noted here that according to reports from Robert Koch Institute, ${ }^{11}$ there has been an increase of incidence and the prevalence of pulmonary tuberculosis in Germany in recent years. ${ }^{7,10,12-19}$ This is primarily caused by multiresistant germs, as well as non-specific or secondary mycotic settlements (-Fig. 1). Moreover, cases of pleural empyema are increasing due to multiresistant bacteria and/ or fungi (including Aspergillus [-Fig. 2]) which is particularly common after partial lung resection and pneumonectomy, especially in immunologically impaired oncologic patients.

The main aim of this article is to present the historical basics of thoracoplasty and discuss its current indications and techniques to provide a better understanding of this method.
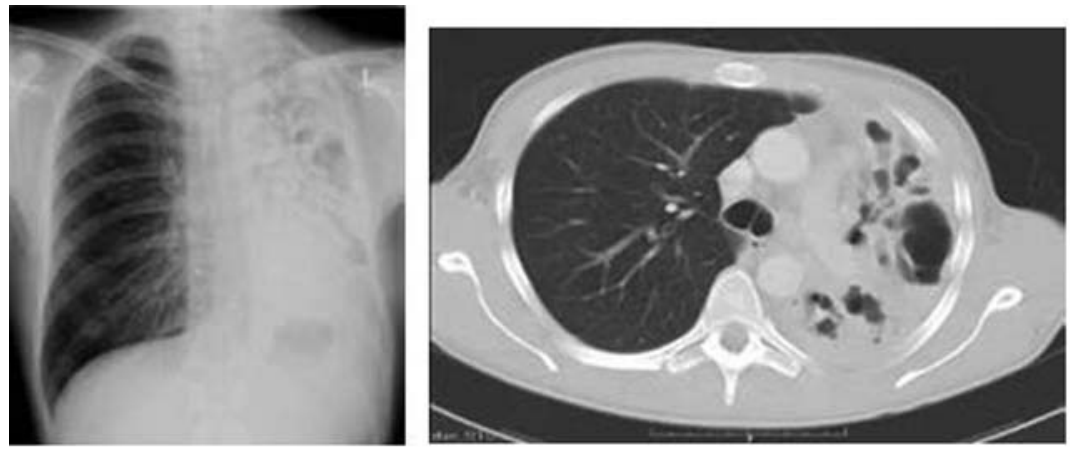

a

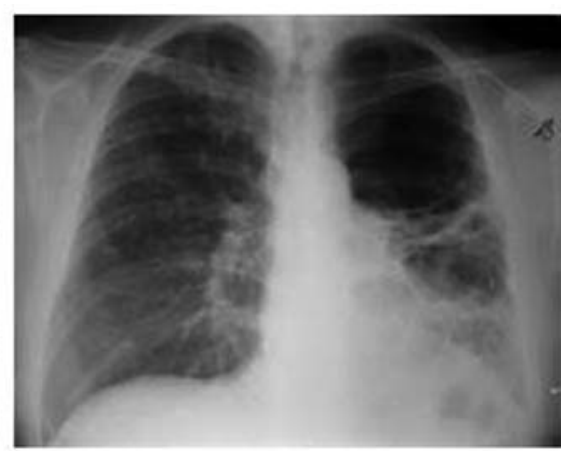

b

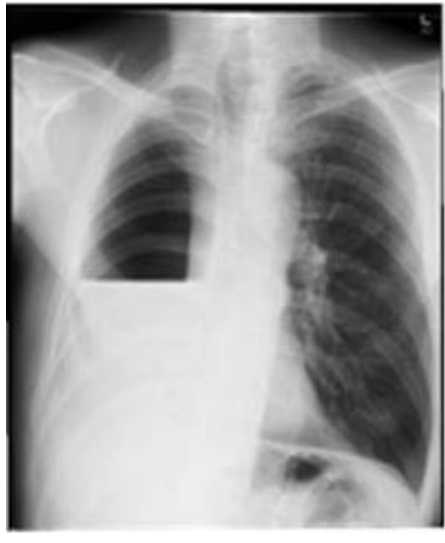

a
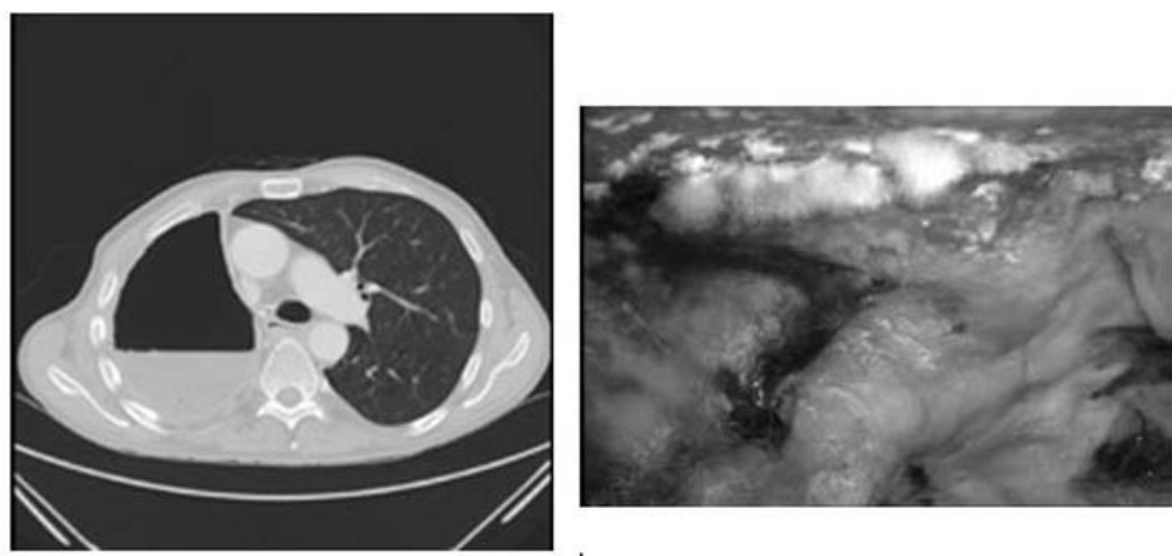

b

Fig. 2 (a) Aspergillus-associated pleural empyema after pneumonectomy on the right-CT and chest X-ray imaging. (b) Aspergillus growth in the pleural cavity after pneumonectomy. 


\section{Actual Indications}

The most common indications for thoracoplasty are the resulting or remaining therapy-resistant filling defects of the pleural cavity and multiresistant infections of lung or pleura. Some examples are as follows:

- Severe fibrotic-cicatricial changes of residual lung after resections (loss of compensatory elasticity).

- Postoperative pleural empyema after lung resection (often in combination with small residual lung).

- Destructive processes in lung tuberculosis.

- Persistent, ( (BPF) in continuity to the empyema cavity.

- Therapy-refractory empyema after pneumonectomy.

\section{Therapeutic Proceeding to Deal with Defects}

The basic principle here is to always perform the minimal intervention possible, which can lead to success. Therefore, a step-by-step therapeutic escalation has to be performed if the preceding step is not successful. The extent of the escalation depends on the localization of the cavity, since apically localized caves (rigid structures on all sides) require thoracoplasty more often than basal residual cavities after lower bilobectomy, due to ascension of the diaphragm. Successful options are pneumoperitoneum, but also muscle lobes (including diaphragm plastics) or transfer of omentum majus.

Strategically, two therapeutic goals should be achieved:

1. Infection cleansing respectively decontamination

(a) Cleaning of pleural cavity by flushing (e.g., drainage or repetitive thoracotomy/thoracoscopy)

(b) Thoracostomy

(c) Vac treatment

(d) Fistula occlusion, if required (by surgery or with stents $)^{20}$

2. Elimination of the cavity

(e) Cave filling with muscular/omental flaps ${ }^{21,22}$

(f) Thoracoplasty as a final "ultima ratio" intervention

(g) Combined procedures (e) + (f)

Based on clinical situation, certain steps might have to be skipped sometimes. ${ }^{23}$

The most common techniques of thoracoplasty are shown (in chronological order) in - Table $\mathbf{1}^{3,5,8,24-32}$

\section{Intrapleural Thoracoplasty}

Intrapleural thoracoplasty (massively mutilating type) is a classical technique described in 1890 by Schede ${ }^{32}$ and is only of a historical significance in the current practice. Bony chest wall (ribs with intercostal musculature and parietal pleura) is resected en bloc. The remaining skin and extra-thoracic muscles fill the space outside the lungs. According to Schede, thoracoplasty is performed mainly when the pleural cavity is so thick and coarse so that sole resection of the ribs will not lead to a collapse of the cavity. ${ }^{33}$ Braun's modification differs from this method only in its multiple-staged surgery approach leading to a better tolerance and lower mortality rates due to minor surgical trauma (-Fig. 3 ).
Table 1 Types of thoracoplasties

\begin{tabular}{|c|l|}
\hline \multicolumn{2}{|l|}{ Intrapleural thoracoplasty } \\
\hline Schede (1890) & $\begin{array}{l}\text { Resection: chest wall } \\
\text { Removed: ribs, intercostal } \\
\text { muscles, and pleura }\end{array}$ \\
\hline Extrapleural thoracoplasty \\
\hline $\begin{array}{l}\text { Sauerbruch (1920 }{ }^{31} \\
\text { Alexander (1937) }\end{array}$ & $\begin{array}{l}\text { Resection: ribs without } \\
\text { periosteum }\end{array}$ \\
\hline Semb (1935) & $\begin{array}{l}\text { Extrafascial pneumolysis } \\
\text { and apikolysis }\end{array}$ \\
\hline Heller (1934) & $\begin{array}{l}\text { Resection: only ribs } \\
\text { Preservation of parietal } \\
\text { pleura, periosteum, } \\
\text { and intercostal muscles }\end{array}$ \\
\hline Bjork (1954) $)^{25}$ & Osteoplastic thoracoplasty \\
\hline Thoracoplasty/Plombage & \multicolumn{2}{|l|}{} \\
\hline Andrews & $\begin{array}{l}\text { Resection: ribs } \\
\text { extrafascially with extra } \\
\text { periostal plombage } \\
(1961)^{24}\end{array}$ \\
\hline
\end{tabular}

\section{Extrapleural Thoracoplasty}

The development of extrapleural thoracoplasty-a huge step forward-is associated with the famous German surgeon F. Sauerbruch. He described the exact course of the procedure in his book "Chirurgie der Brustorgane" (1920). ${ }^{30}$ The term "hockey stick cut" ${ }^{31}$ for access to thoracoplasty was also introduced by F. Sauerbruch ( - Fig. 4). In this procedure the rib periosteum, the intercostal musculature, and the parietal pleura are not resected. As the dome of the pleural cavity is located at the level of the cervical spine and is fixed with strong muscular tissue and fibrous ligaments, the result of this technique is only a lateral collapse of the pleural space.

The most important modification of locally adapted extrapleural plastic surgery was presented by E. Heller, ${ }^{27}$ known as Jalousie-Plastik (minimally mutilating type). In this method, the skin incision is made above the area of the pleural empyema. Subsequently, the ribs are resected intraperiosteally, followed by parallel transperiosteal incisions of the rind. On the one hand opening the pleural cavity makes it possible to carry out a debridement there. On the other hand, by diminishing the tension it is possible to sink the soft parts into the thoracic cavity (-Fig. 5). In the current practice, this operating procedure is occasionally applied in a modified form, proceeded by a conditioning vacuum therapy and combined, if appropriate, with a myoplasty.

\section{Conventional Posterolateral Thoracoplasty (Type Alexander)}

The method of extrapleural thoracoplasty was further developed by Alexander. The main principle of this three-staged procedure is the subperiosteal resection of the ribs maintaining the muscles to achieve a collapse of the chest wall. Background-paradoxical breathing should be avoided by means of scarring stabilization. According to Alexander, ${ }^{34}$ the method of thoracoplasty is still in use for treatment-resistant pleural 

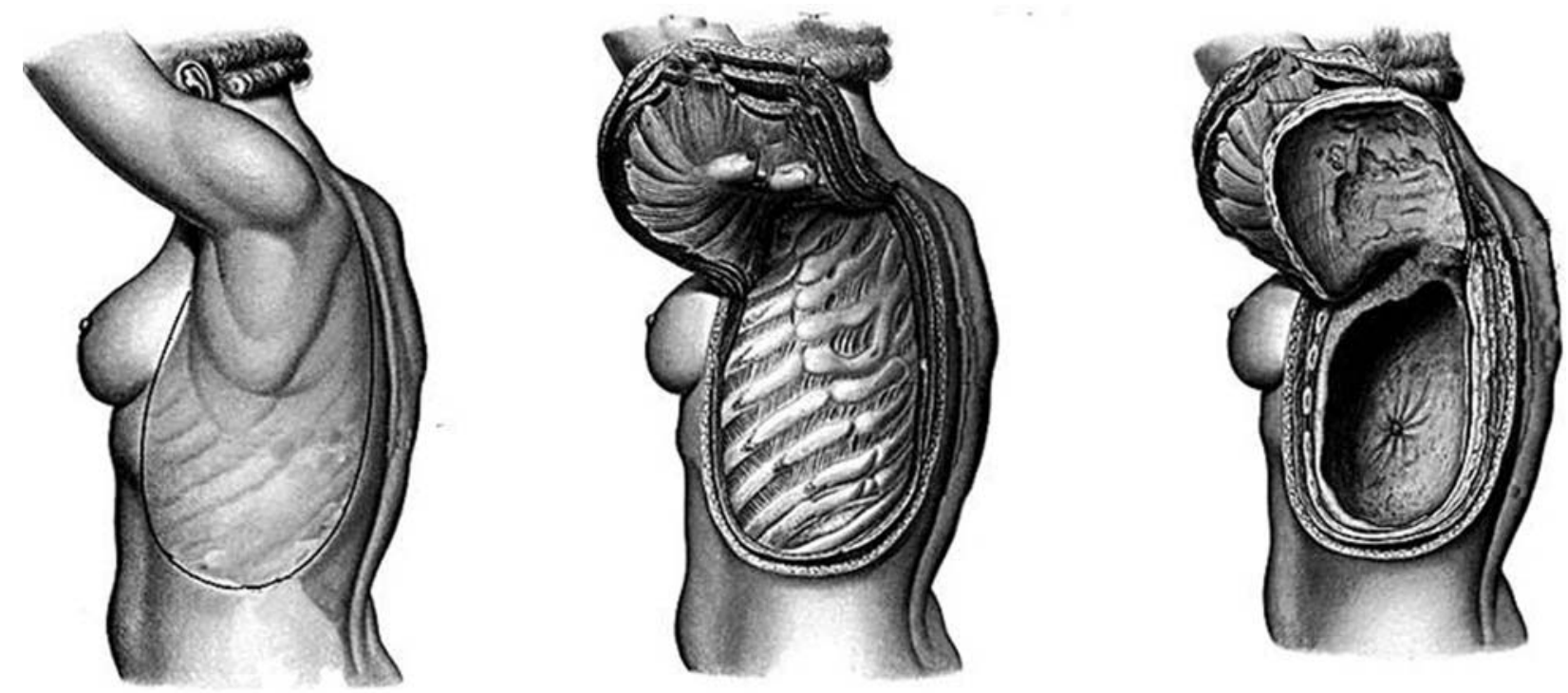

Fig. 3 Intrapleural thoracoplasty by Schede for the elimination of a large empyema cavity.
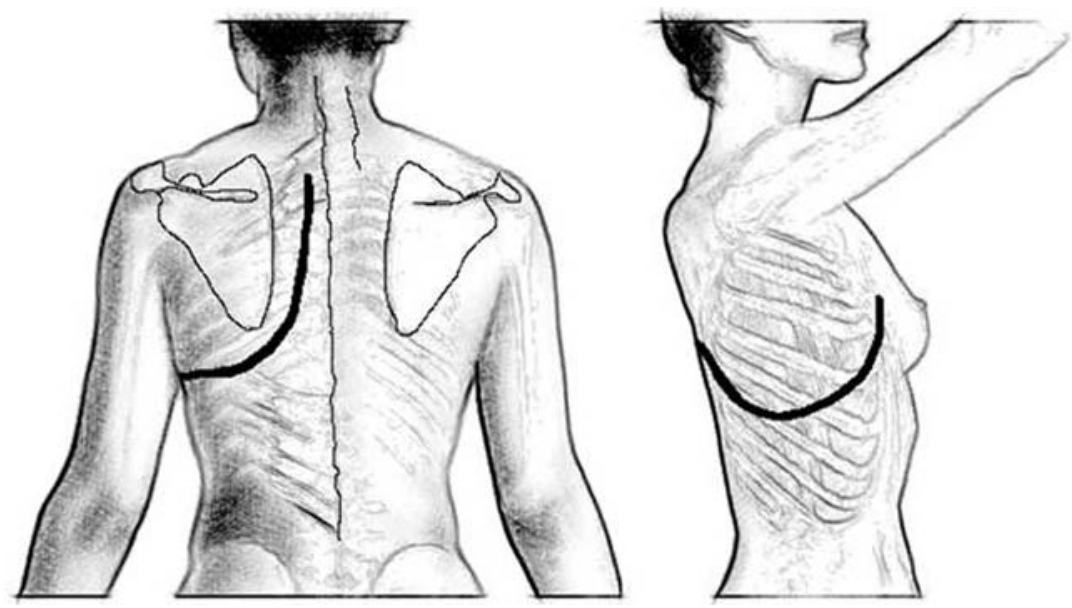

Fig. 4 "Hockey stick" cut by Sauerbruch.
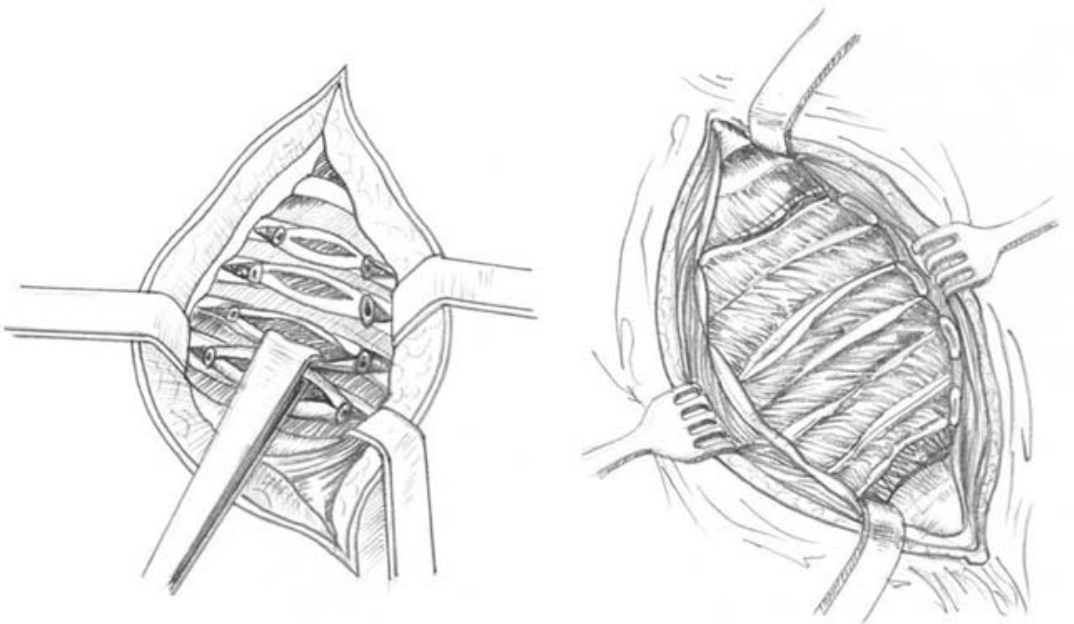

Fig. 5 The operating sequence Jalousie-plastic by E. Heller. 


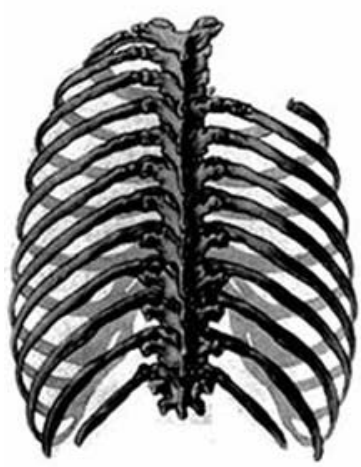

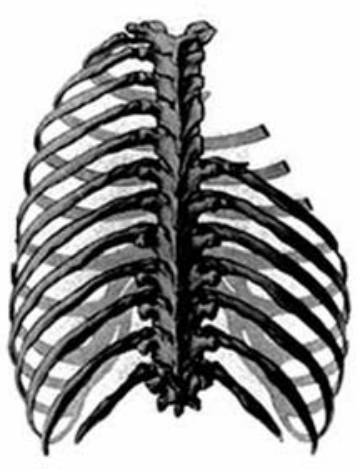

a
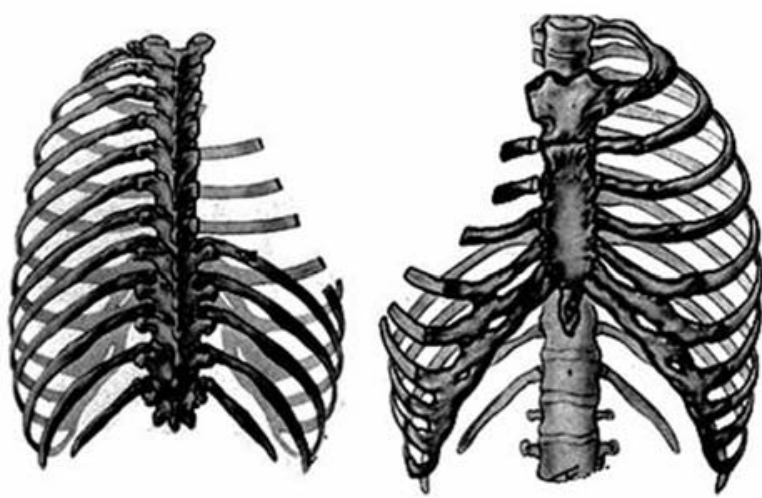

b

Fig. 6 (a) Stage I and II after Alexander (resection 2, 3 rib complete, posterior $3 / 4$ of 4 th and posterior $1 / 2$ of 5 th rib), Stage III by Alexander (complete resection of 4 and 5 rib, resection posterior $3 / 4$ of the 6 - and posterior $1 / 2$ of the 7 rib. (b) Final result.

empyema after partial lung resection or pneumonectomy. The ribs are resected in two or more sessions (- Fig. 6).

Deepest level is one rib below the cavity as a caudal resection limit. According to the illustration in Fig. 6, the ventral resection line runs obliquely, so ventrally remain ribs of different lengths. Caudal resection is also performed near the spine. After the resektion of the seventh rib, the mobility of the scapula can cause problems, therefore a resection of the lower third of the scapula may be necessary.

Sauerbruch $^{30,31}$ and Semb ${ }^{3}$ suggested another surgical technique for removing the remaining apical cavity, which is called extrapleural apicolysis. This procedure means a vertical relaxation in addition to thoracoplasty according to Alexander. This technique is more complex due to the ligaments, which have to be removed at the top or at the apex, being directly adjacent to the subclavicular vessels and the nerve fascicles of the brachial plexus.

It looks like this is a never-ending discussion 1st rib resection. Today, only in the case of extensive thoracoplasty (for example, in the case of TB-induced pleural sensation) a resection of the first rib may be justified. ${ }^{15}$ With or without a resection of the first rib, apicolysis remains an elementary component of any thoracoplasty.

\section{Combined Procedures: Thoracoplasty with Alloplastic Replenishing of the Residual Cavity}

Thoracoplasty can be combined with sealing ( - Fig. 7a). The techniques described above, as well as the original thora-
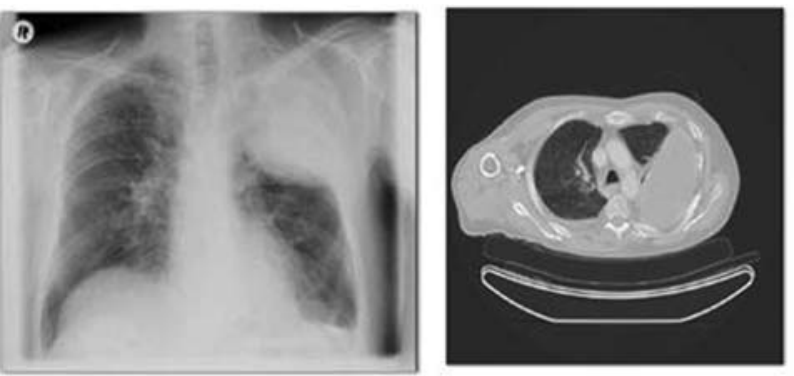

a coplasty, do not fill up pleural space. In case of incomplete obliteration of the remaining spaces, various materials (e.g., oil, gelatin, rubber, wax, Lucite and silicone) have been used to seal these spaces. Due to severe, consecutive septic complications, these materials are hardly ever used nowadays ( - Fig. 7b). For quite time, thoracomyoplasty has been accepted as the best method to eliminate the residual pleural cavity because it causes only negligible cosmetic defects. ${ }^{17,19}$

\section{Thoracomyoplasty According to Andrews}

Thoracomyoplasty, described by Andrews in 1961, ${ }^{24}$ is based on preparatory work by Nissen. ${ }^{29}$ It particularly includes muscle lobes with subcutaneous fat tissue permitting volume gain with a general increase in weight, and was primarily introduced for the treatment of the tubercular empyema.

The operative technique comprises the following steps:

1. Resection of the ribs lying above the empyema cavity.

2. Opening the cave along the ribs.

3. Clearing the fibrous rind in a way that the muscles can collapse down to lung or mediastinal level.

4. Placing a muscle lobe (-Fig. 8a-c), alternatively an omentum majus flap into the residual cavity, possibly with fixation on the lung.

Good functional and cosmetic results can be achieved using this technique. ${ }^{35}$

Fig. 7 (a) Oleothorax on the left. (b) Infected oleothorax.
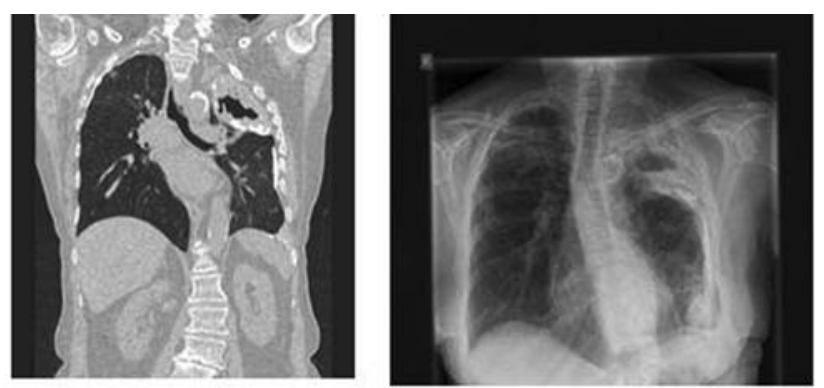

b 
a

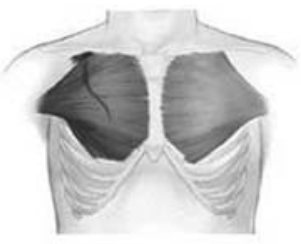

b

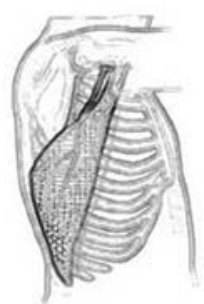

c

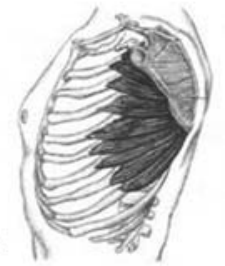

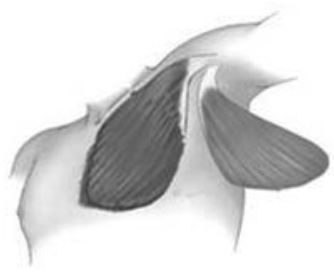
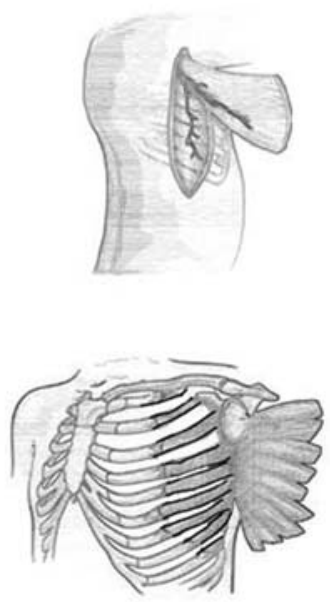

Fig. 8 Preparation of the muscle lobes-(a) M. pectoralis major, (b) M. latissimus dorsi, (c) M. serratus anterior-to intrapleural interposition.

\section{Modern Methods of Thoracoplasty}

Currently two variants of thoracoplasty procedures, are mainly used: modified thoracoplasty according to Lampl and video-assisted extrapleural thoracoplasty according to Giller.

\section{Thoracoplasty (Modified According to Lampl)}

Incision

"Sauerbruch hockey stick" cut modified according to Lampl ( - Fig. 9); course parallel to the medial and caudal border of the scapula. ${ }^{36}$ It ends $\sim 5 \mathrm{~cm}$ below the scapula.

\section{Rib Resection}

Ribs are removed subperiosteally, starting with the resection of the third rib from the transverse processus to the medioclavicular line, then ribs $2-6$ are resected ( - Fig. 10). Subsequently, periosteum and the underlying pleural cavity are incised according to Heller's Jalousie-Plastik, beginning in the area of the fifth rib, cutting through periosteum and the thickened pleura. The number of longitudinal incisions depends essentially on the thickness of pannus (-Fig. 10). A debridement as well as a lavage of the cavity (e.g., with physiological electrolyte solution or antiseptics) can take place via these incisions. At the same time, it is also possible to check thoracoscopically whether the soft tissue layer nestles completely in the posterior recess. If this is not sufficient, resection of the rib heads is necessary. In more than two-thirds of patients this is the case.

This approach allows scapula and their muscles around (m. subscapularis) to pass into the thoracic cavity. To achieve this, a limited resection of the seventh rib (at least dorsal part) is often necessary (-Fig. 10). However, a resection of the scapula is not indicated. Maintaining the integrity of the serratus anterior muscle and its scapular approach reduces the functional limitation of the corresponding upper extremity.

A resection of the first rib is not required. After dorsolateral mobilization of the pleural sac, no residual space remains. Neurological or vascular complications, especially in postpneumonectomy spaces, are very rare. Furthermore, the left first rib ensures a better stability of the shoulder girdle, with a significantly lower scoliosis ${ }^{37}$ grade in the further course. The extent of thoracic deformity depends not only on the extent of thoracoplasty, but also on the patient's habitus (thickness of the soft tissue).

\section{Drainage}

Finally, the insertion of two tubes (e.g., 24- or 28-French) is required; one of them should be placed intrapleurally and the second one is placed between the muscle layers. A suction strength $10-20 \mathrm{~mm} \mathrm{Hg}$ is favorable.
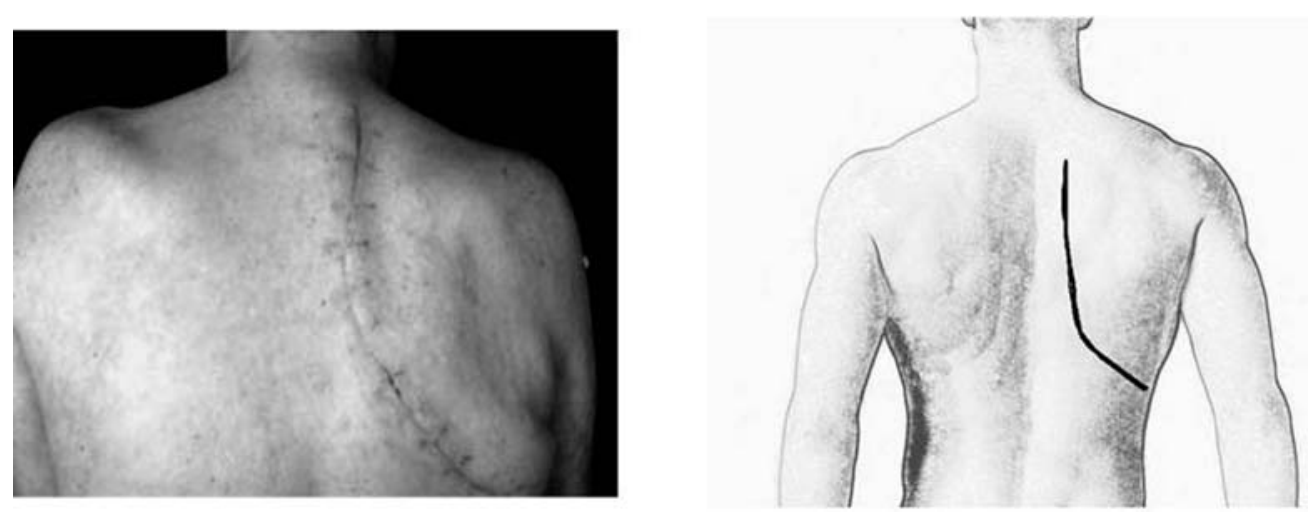

Fig. 9 Modified according to Lampl "Sauerbruch hockey stick" cut. 

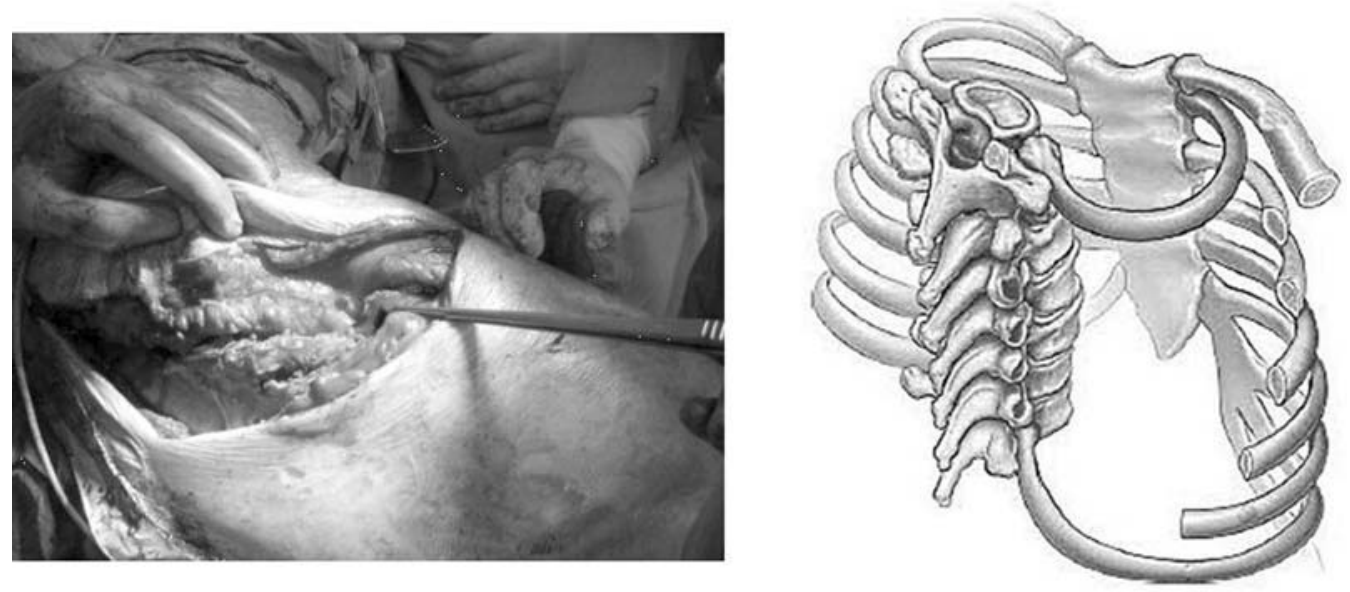

Fig. 10 Thoracoplasty-operative technique by Lampl.

\section{Video-assisted Extrapleural Thoracoplasty according to Giller}

Giller suggested a video-assisted variant of thoracoplasty ${ }^{38}$ as an alternative to the previously used methods. The main advantage of this technique is a significantly less surgical trauma, with the muscle bel particularly spared. Similar to other minimally invasive surgical techniques, the postoperative pain perception is significantly reduced in comparison to the classical technique. A further advantage of this method is a smaller deformation of the thoracic cage ( $\mathbf{- F i g . 1 1 b}, \mathbf{c}$ ).

Access: Skin incision paravertebrally, ca. $5-10 \mathrm{~cm}$, parallel to the medial margin of the shoulder blade ( $\mathbf{F i g} .11 \mathbf{a}$ ), starting at level III of the breast vertebral body. The skin and subcutaneous tissues are severed by layers. Muscles (trapezius, latissimus dorsi, rhomboideus major) are separated sparingly.
Afterwards, the back muscles with the scapula are detached from the ribs under video endoscopic control and lifted with the hook (-Fig. 11b). The access for the optic trocar should be $\sim 2 \mathrm{~cm}$ cranial to the incision. All further operations are performed under video endoscopic control.

By expanding the musculus erector spinae, a paravertebral access to the sections of the ribs is made. The incision of the periosteum is performed with an electric knife. Intercostal musculature and periosteum are detached from the ribs. The fixation of the tape apparatus of the thoracic spine is partially severed. The third rib is mobilized and removed. Then the second rib is resected followed by the resection of ribs 4,5 , and 6 from the anterior over the medial to the

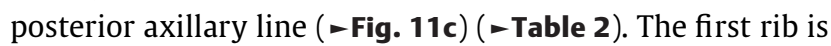
resected ventrally up to the cartilaginous attachment. In the presence of a tuberculous cavern, the extrapleural

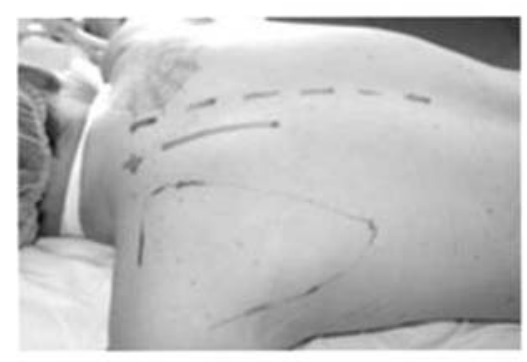

a

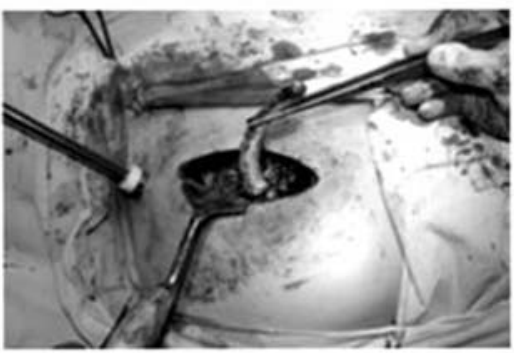

C
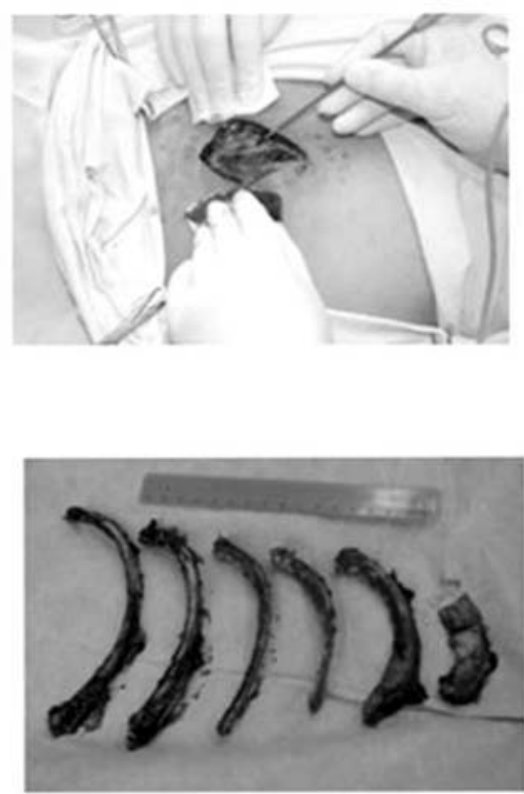

d

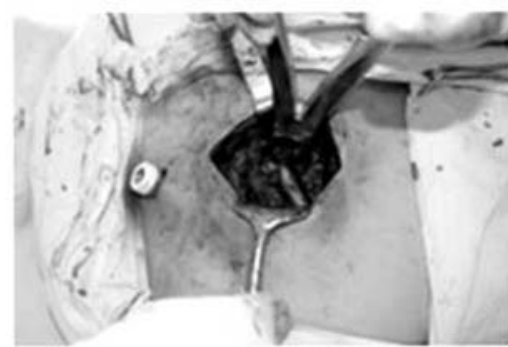

b

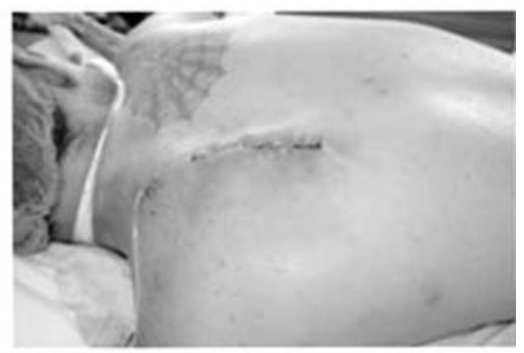

e

Fig. 11 The course of thoracoplasty surgery by (a) Giller Access, (b-c) Op-situs, (d) resected ribs, (e) result. 
Table 2 Margins of the rib resection for video-assisted extrapleural thoracoplasty by Giller

\begin{tabular}{|l|l|}
\hline I, II and III ribs & to the cartilage areas of the ribs \\
\hline IV rib & to anterior axillary line \\
\hline V rib & to medial axillary line \\
\hline VI rib & to posterior axillary line \\
\hline
\end{tabular}

mobilization of the apex of the lung (apicolysis) is performed. After the application of suction drainage, the wound closure takes place. In this technique, it is particularly important to remove the fifth and sixth ribs to achieve a sufficient collapse of the thoracic wall (-Fig. 12).

\section{Discussion}

The decline of thoracoplasty is fundamentally linked to the introduction of successful drug therapy of pulmonary tuberculosis. Thoracoplasty has changed over the course of time and nowaday is presently rarely only used when standard/ antibiotic therapy or previous surgery fail. ${ }^{8}$ Thoracoplasty has changed over the traditional techniques of thoracoplasty have been replaced by less- invasive surgical procedures, which is combined with myoplasty due to the dangers of demolition and loss of function. ${ }^{13,36}$

However, the basic principles have not changed. All the modifications of thoracoplasty are merely different techniques to reach these two basic goals: the chest wall should be brought close to the lung or the lung should be brought close to the chest wall. Extrapleural apicolysis, ${ }^{3}$ partial resection of the scapula to resect less ribs, ${ }^{39}$ and the different modifications of thoracoplasty $1,5,6,9,16,17,25,26,28,34,40$ using myoplasty as a filling are just different ways to achieve these goals. ${ }^{7,16}$

The question here would be-is thoracoplasty still justified? The answer is a clear YES, despite some limitations associated with this surgical technique. $7,8,15,17,19,36,41,42$
Even though a large number of specific, nonspecific, and mixed infections in the thoracic cavity can be treated with antibiotic/antitubercular medications, these treatments are not always successful. Increasing numbers of multiresistant tuberculosis (meanwhile also in Germany) ${ }^{11,12}$ require thoracoplastic surgery as an ultima ratio procedure in some cases. Unfortunately, nowadays we have a very limited knowledge of this surgical technique. Patients are likely to face a desperate situation if standard operating procedures are not successful, especially when previously applicable well-known surgical methods are either used incorrectly or forgotten. The positive outcomes of surgical treatment (especially thoracoplasty for patients with multiresistant tuberculosis in Russia) $)^{28,42-45}$ and the increasing number of resistant tuberculosis in Europe ${ }^{11,12}$ confirm the relevance of this approach.

It is evident that additional soft tissue transfer for cavity filling (microvascular muscular lobes, desepithelized myocutaneous lobes, or omentoplasty) can often be decisive for the final success, as well as conditioning of the cavity by vacuum treatment can provide a very important contribution. Nevertheless in a certain number of patients the combination with thoracoplastic procedures is needed to achieve a complete healing.

For this reason, it is important to reintroduce these old and time-tested procedures and in some cases to adapt them to current challenges, with the minor traumatic techniques of thoracoplasty and myoplasty.

\section{Summary}

As described above sections, different variations of thoracoplasty have been developed in the last century. While historic procedures, in absence of alternative and additive treatment options for tuberculosis, usually caused severe destructions, sophisticated minimally invasive variants have been developed. Modern procedures are functional, better cosmetically and significantly less traumatic compared to the traditional procedures. The modern techniques
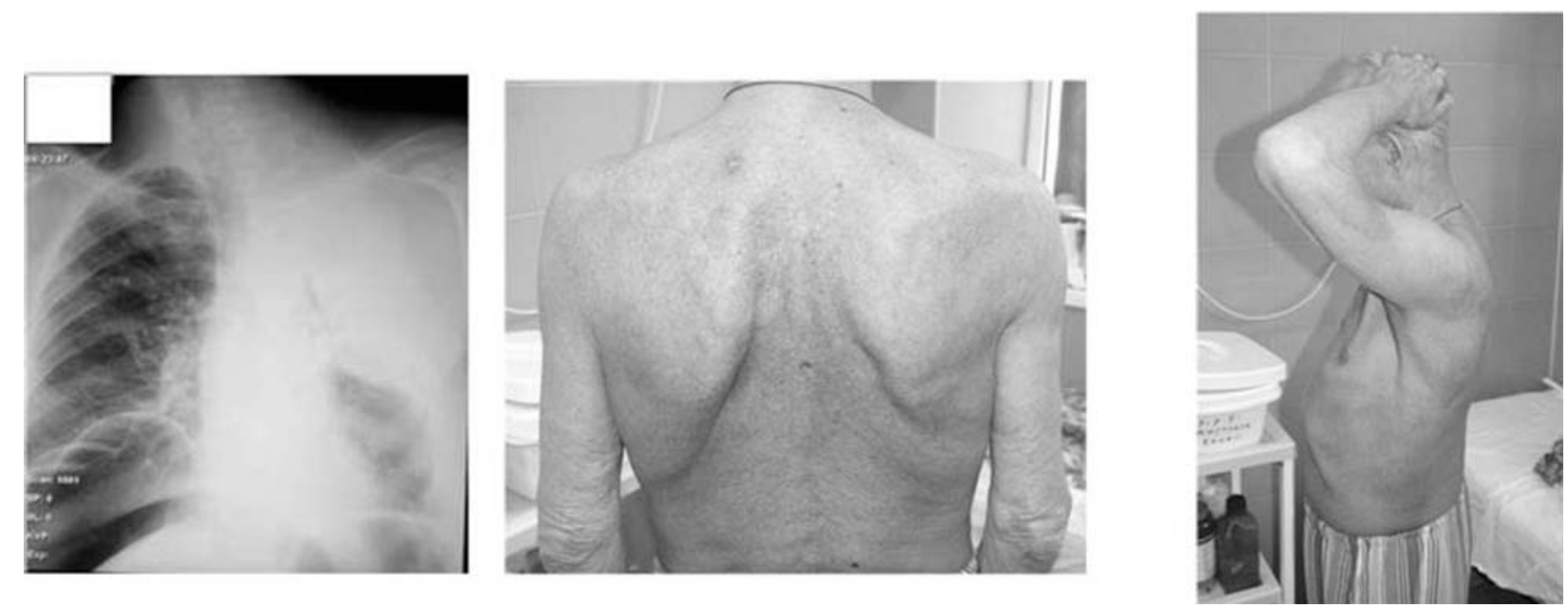

Fig. 12 Postoperative result. 
also permit combinations with partly extended soft tissue transfer. Nevertheless, the main principle of this operation remains unchanged. If the lung cannot be brought closer to the thoracic wall, the thoracic wall must be brought closer to the lung.

Unfortunately, robust knowledge of these techniques has diminished considerably. The aim of this article is, therefore, to revive interest in important surgical procedures that are still beneficial to some patients. A look at the historical sources is recommended (especially reference number 33 in the bibliography).

\section{Conflict of Interest}

None declared.

\section{References}

1 Good H. Zur Kollapsmechanik der Thorakoplastik. Beitr Klin Tuberk Spezif Tuberk-Forsch 1949;102:202-215

2 Odell JA. The history of surgery for pulmonary tuberculosis. Thorac Surg Clin 2012;22(03):257-269

3 Semb C. Thoracoplasty with extrafascial apicolysis. BMJ 1937; 2(4004):650-666, 4

4 Stefko WH, Nikitowa AN. Zur pathologischen Anatomie der Thorakoplastik. Beitr Klin Tuberk Spezif Tuberk-Forsch 1935; 86:317-327

5 Benjamin J. Pomerantz JCC, Jr, and Marvin Pomerantz. The Schede and modern thoracoplasty. Oper Tech Thorac Cardiovasc Surg 2000;5(02):128-134

6 Schmidt PG. Zur Entwicklung der Thorakoplastik. Beitr Klin Tuberk Spezif Tuberk-Forsch 1951;105:463-469

7 Botianu PV, Botianu AM. Thoracomyoplasty in the treatment of empyema: current indications, basic principles, and results. Pub Med 2012;2012:418-514

8 Hecker E, Hecker HC, Hecker KA. [Pleural empyema-treatment strategies in light of etiology]. Zentralbl Chir 2013; 138(03):353-377, quiz 378-379

9 Deschamps C, Pairolero PC, Allen MS, Trastek VF. Management of postpneumonectomy empyema and bronchopleural fistula. Chest Surg Clin N Am 1996;6(03):519-527

10 Weber J, Gräbner D, al-Zand K, Beyer D. Empyema after pneumonectomy-empyema window or thoracoplasty? Thorac Cardiovasc Surg 1990;38(06):355-358

11 [Anonymous]. Epidemiologisches Bulletin 10-11 / 2016. Published on edoc: 2016-03-21T10:31:00Z, access: 2017-0109T13:05:08Z.2016;

12 [Anonymous]. Epidemiologisches Bulletin 50 / 2016. Published on edoc: 2016-12-19T12:34:00Z, access: 2017-0109T12:53:54Z.2016;

13 Deslauriers JGJ. Thorakoplasty. In: G. Alexander Patterson M, F. Griffith Pearson, Joel D. Cooper, Jean Deslauriers, Thomas W. Rice, James D. Luketich, and Antoon E. M. R. Lerut, eds. Pearson's Thoracic and Esophageal Surgery. 3rd ed. Philadelphia:Churchill Livingstone, an imprint of Elsevier Inc; 2008:1159-1169

14 Ernst M, Nies C. Die thoracoskopische Therapie des Pleuraempyems nach Pneumonektomie. Chirurg 1999;70(12):1480-1 483

15 Fell C. Thoracoplasty: indications and surgical considerations. In: Shields TW, LoCicero J, Reed CE, Feins RH, eds. General Thoracic Surgery. 7th ed. Philadelphia: Wolters Kluwer Health/Lippincott Williams \& Wilkins; 2009:860-878

16 García-Yuste M, Ramos G, Duque JL, et al. Open-window thoracostomy and thoracomyoplasty to manage chronic pleural empyema. Ann Thorac Surg 1998;65(03):818-822
17 Hysi I, Rousse N, Claret A, et al. Open window thoracostomy and thoracoplasty to manage 90 postpneumonectomy empyemas. Ann Thorac Surg 2011;92(05):1833-1839

18 Korpusenko I. Application of minimally invasive extapleural thoracoplasty in patients with bilateral tuberculosis of the lungs. Novosti Khirurgii 2015;23:37-43

19 Stefani A, Jouni R, Alifano M, et al. Thoracoplasty in the current practice of thoracic surgery: a single-institution 10-year experience. Ann Thorac Surg 2011;91(01):263-268

20 Lampl L. Bronchial stump insufficiency and its treatment. In: Schlag G, Wolner E, Eckersberger F, eds. Fibrin Sealing in Surgical and Nonsurgical Fields: Volume 6: Cardiovascular Surgery Thoracic Surgery. Berlin, Heidelberg: Springer Berlin Heidelberg; 1995:201-203

21 Brunner A. Die chirurgische Behandlung der Lungentuberkulose. In: Chirurgie der Lungen und des Brustfelles. Berlin, Heidelberg: Springer Berlin Heidelberg; 1938:67-179

22 Clagett OT, Geraci JE. A procedure for the management of postpneumonectomy empyema. J Thorac Cardiovasc Surg 1963; 45:141-145

23 Kuhtin O, Kenanidis T, Haas V, Lampl L, Schulz T. [Differential treatment strategy of pleural empyema in a post-pneumonectomy cavity]. Pneumologie 2015;69(08):463-468

24 Andrews NC. Thoraco-mediastinal plicature (a surgical technique for chronic empyema). J Thorac Surg 1961;41:809-816

25 Bjork VO. Thoracoplasty, a new osteo plastic technique. J Thorac Surg 1954;28(02):194-211

26 Brock R. Osteoplastic thoracoplasty. Thorax 1955;10(01):1-8

27 Heller E. Über Verhütung und Behandlung der Empyemresthöhlen. Chirurg 1934;6:297-302

28 Krasnov D, Krasnov V, Skvortsov D, Felker I. Thoracoplasty for tuberculosis in the twenty-first century. Thorac Surg Clin 2017; 27(02):99-111

29 Nissen R. Die Eingriffe im Bereiche der Brusthöhle. In: Kirschner M, ed. Allgemeine und Spezielle Chirurgische Operationslehre. Heidelberg: Springer; 1940

30 Sauerbruch F. Die Chirurgie der Brustorgane. Berlin, Heidelberg: Springer Berlin Heidelberg; 1920

31 Sauerbruch F, Elving H. Die extrapleurale Thorakoplastik. In: Kraus F, Minkowski O, Müller F, et al, eds. Ergebnisse der Inneren Medizin und Kinderheilkunde. Berlin, Heidelberg: Springer Berlin Heidelberg; 1913:869-990

32 Schede M. Die Behandlung der Empyeme. Verh Innere Med Wiesbaden 1890, DOI: 41-141

33 Kleinschmidt O, Kirschner M. Die Eingriffe an der Brust und in der Brusthöhle. In: Kirschner $M$, ed. Allgemeine und Spezielle Chirurgische Operationslehre. Berlin: Julius Springer; 1940:1072

34 Alexander J. Some advances in the technic of thoracoplasty. Ann Surg 1936;104(04):545-551

35 Krassas A, Grima R, Bagan P, et al. Current indications and results for thoracoplasty and intrathoracic muscle transposition. Eur J Cardiothorac Surg 2010;37(05):1215-1220

36 Lampl L. Thoracoplasty. In: Dienemann HC, Hoffmann H, Detterbeck FC, eds. Chest Surgery. Berlin, Heidelberg: Springer Berlin Heidelberg; 2015:447-456

37 Hug O. Thorakoplastik und Skoliose: Mit 64 Abbildungen: F. Enke; Stuttgart; 1921

38 Giller DB. Miniinvazivnye dostupy s ispol'zovaniem videoendoskopicheskoj tehniki v torakal'noj hirurgii [Miniinvasive video-assisted accesses in thoracic surgery]. Khirurgiia (Mosk) 2009;(08):21-28

39 Viereck H-J. Die Thorakoplastik mit partieller Resektion der Scapula. Langenbecks Archiv für klinische. Chirurgie 1960; 293:441-451

40 Belcher JR. Surgical collapse therapy in pulmonary tuberculosis. Postgrad Med J 1954;30(344):300-304

41 Giller DB, Kostenko AD, Giller BM, Giller GV. [Treatment of patients with destructive pulmonary tuberculosis with concomitant diabetes mellitus]. Probl Tuberk 2002;(11):18-21 
42 Giller DB, Murgustov IB, Martel' II, Enilenis II, Glotov AA, Kesaev OS. Povtornye rezekcii legkogo u bol'nyh s posleoperacionnym recidivom tuberkuleza $\mathrm{v}$ operirovannom legkom [Repeated lung resection in patients with postoperative recurrent tuberculosis in the operated lung]. Khirurgiia (Mosk) 2015; 8(8 Pt 2):14-19 10.17116/hirurgia20158214-19

43 Giller DB, Bizhanov AB, Khasanshin GS, Trishina LV, Klestova AA. Puti povyshenija effektivnosti lechenija vpervye vyjavlennyh bol'nyh destruktivnym tuberkulezom legkih s bacillovydeleniem [Treatment of the newly diagnosed destructive lung tuberculosis with elimination of bacilli]. Khirurgiia (Mosk) 2013;(06):83-87
44 Giller DB, Martel' II, Imagozhev YG, Enilenis II, Bizhanov AB, Glotov AA. Rezekcija edinstvennogo legkogo i pnevmonektomija posle rezekcii protivopolozhnogo legkogo $\mathrm{v}$ lechenii tuberkuleza [An experience of single lung resection and pneumonectomy after contralateral lung resection in treatment of tuberculosis]. Khirurgiia (Mosk) 2015;(09):35-42 10.17116/hirurgia2015935-42

45 Giller DB, Shakhaev Ala, Vasil'eva IA, et al. Effektivnost' chastichnyh rezekcij legkih u bol'nyh tuberkulezom s mnozhestvennoj lekarstvennoj ustojchivost'ju [Efficiency of partial pneumonectomies in patients with multidrug-resistant tuberculosis]. Probl Tuberk Bolezn Legk 2008;(05):6-10 